\title{
原著
}

\section{分泌型 $\operatorname{IgA}$ の生物 学 的 活 性}

一一特に陲液中の分泌型 IgA による口腔常在菌に対する凝集活性—

佐 藤 信 義

東京医科菌科大学蔽学部口腔細菌学教室（指導：堀川高大教授）

（1978年10月14日 受付）

\section{Biological Activity of Secretory IgA}

_-Particularly agglutinating activity of salivary SIgA against oral indigenous microorganisms -

Nobuyoshi Sato

Department of Oral Microbiology, School of Dentistry, Tokyo Medical and Dental University

(Director: prof. Takahiro Horikawa)

要旨：ヒト耳下腺唾液より，イオン交換法ならびにゲル滤過法によって分泌型 IgA を分離精製し，主要 な口腔常在菌15種18株に対する凝集活性を測定した。分泌型 IgA は13株の細菌に対して凝集活性を示した。 特に凝集価の高い細菌は, Lact. fermenti およびStr. sanguis であった。一方, Str. mutans B13, Str. salivarius, Bact. matruchotii, Bact. melaninogenicus およびSelenomonas では凝集がみられなかった。

\section{緒言}

外分泌液中の主要な免疫グロブリンである分泌 型 $\operatorname{Ig} \mathrm{A}(\mathrm{SIg} \mathrm{A})^{26)}$ に関しては, 近年, 多くの報告 がなされているが23), 構造面に関する研究が多く, 生物学的活性を主体とした基礎的実験についての 知見はきわめて乏しい現状である。通常 SIgAの 活性として報告されているのは, ウイルス中和反 応 $^{3,7,19)}$, 細菌凝集反応 ${ }^{27)}$, 溶菌反応 ${ }^{1,16)}$ などのみ である。

また，SIgA は唾液中に拈いても主要な免疫グ ロブリンであり ${ }^{26)}$ ，ヒトの口腔内に沶いて常在菌 を凝集し, 二次的に何らかの生物学的活性を発揮
するものと考光られている12,28)。しかしながら， 睡液より分離した SIgAによる主要な口腔常在菌 の凝集についての報告は少なく9,24,28), 唾液 $\operatorname{SIgA}$ の特異性については不明の点が多い。

今回, ヒト耳下腺唾液 (HPS) より SIgA を分 離精製し, 主要な口腔常在菌に対する活性を測定 し，特異性を検討したので報告する。

\section{材料と方法}

\section{SIgA の分離精製}

刺激耳下腺唾液を採取し，おもに Tomasi の方 法 ${ }^{26)}$ に従ってイオン交換法ならびにゲル慮過法で 分離精製した。 
約20名より採取した HPS はただちに蒸留水中 に一晚透析し, 凍結乾燥して使用するまで $4^{\circ} \mathrm{C}$ 中 に保存した。

DEAEイオン交換クロマトグラフィーは, DE52 (whatman 社製) を用いて, (1) $\mathrm{pH} 7.4,0.01$ $\mathrm{M}$, (2) $\mathrm{pH} 6.2,0.1 \mathrm{M}$, (3) $\mathrm{pH} 4.8,0.3 \mathrm{M}$ の 3 種 のPBS による stepwise 法で行った。その際, 凍 結乾燥した HPS は約 $100 \mathrm{mg} / \mathrm{ml}$ の割合で $\mathrm{pH}$ 7. 4, 0.01 M PBS に溶解し, PBS 中に一晚透析

し，遠沈して使用した。

ゲル濾過は, Sephadex G-200 (Pharmacia 社 製）および Bio-Gel A15m（BIO•RAD 社製）を 使用して行った。カラムは $2.5 \mathrm{~cm} \times 100 \mathrm{~cm}$ (pharmacia 社製）のものを用い, $\mathrm{pH} 7.4,0.14 \mathrm{M}$ PBS 0.2 M NaCl の緩衝液で溶出した。

\section{2. $\operatorname{SIgA}$ の同定}

免疫電気泳動は通法に従い, Veronal Buffer （pH 8.6， $\mu=0.05 ） を$ をいて $1 \%$ agarose gel (Sigma 社製) 平板上で行った。

二元免疫拡散法は, 上記と同様の $1 \%$ agarose gel 平板上で Ouchterlony 法で行った。

単純放射免疫拡散法 (SRID) は, Tripartigen IgA (Behring 社製)を使用して行った。

抗 HPS 技よび抗 SIgA 抗血清の作製法は, Hurlimann et al.17)の方法に従って行った。すな わち, HPS および分離精製した SIgA 分画の生 食溶液を等量の Freund の Complete adjuvant とともに emulsion とし, ウサギの足蹠と背部皮 下に注射し,さらに約 4 週後に追加免疫した。 SIgA 分画で免疫して得られた抗血清は, Cohn Fraction II (Chemical credentals 社製) で吸収 して使用した。

抗ヒト IgA 抗血清は Behring 社製を, 抗ヒト $\mathrm{SC}$ 抗血清は DAKO 社製を使用した。

\section{3. 使用細菌}

主要な口腔常在菌のうち, 次の 15 種 18 株の細菌 を使用した。

Str. mutans HS6 (serotype $\mathrm{a}^{5)}$ ), Fa-1 (b), B13 (d), LM 7 (e), Str. salivarius (ATCC 9758), Str. sanguis (E206), Str. mitis (ATCC 9811), Veill.
alcalescens(ATCC 17746), Veill.parvula (ATCC 17743), Act. viscosus (ATCC 15987), Lact. acidophilus (IAM), Lact. casei (IAM), Lact. fermenti (IAM), Bact. matruchotii (ATCC 14266), Lept. buccalis (ATCC 14201), Fusobacterium, Bact. melaninogenicus, Selenomonas ${ }^{25)}$.

このらち, Fusobacteriumおよび Bact. melaninogenicus は唾液より分離した新鮮分離株であ る。培養に用いた培地は, Veillonella では Rogosa ${ }^{21)}$ の培地, Lactobacillus では Rogosa の SL 培地, Fusobacterium では Falkler, et al. ${ }^{8 `}$ の記 載した modified trypton 培地, Bact. melaninogenicus では Heart Infusion (BBL) 培地, 他は Brain Heart Infusion (BBL) 培地である。ただ し, Actinomyces, Leptotrichia および Fusobacterium の 3 菌種は弱い自己凝集を示したので, 斎藤 ${ }^{22}$ に従って $1 ： 250$ の割合で Tween 80 を培 地中に加えた。また Bact. melaninogenicus では 培地中にへミンおよび Vitamin $\mathrm{K}^{10)}$ を加えた。

細菌は培養後 9,000g で10分間遠沈し, PBSで 2 回洗浄した後 $0.5 \%$ ホルマリンを加えた PBSに 再浮遊させ， $4{ }^{\circ} \mathrm{C}$ 中に使用するまで保存した。

\section{4. 細菌凝集反応}

細菌の PBS 浮遊液は吸光度 $550 \mathrm{~nm}$ で 1.0 に 調整した。

精製 SIgA は，SRIDにより IgA 換算量で, 120 $\mu \mathrm{g} / \mathrm{ml}$ に調整した。HPS中の $\operatorname{Ig} \mathrm{A}$ 量は $12 \mu \mathrm{g} / \mathrm{ml}$ であったので, $1 \mathrm{ml}$ 当たりの $\operatorname{Ig} \mathrm{A}$ 含量は約 10 倍 となっている。

このSIgA溶液を試験管に $0.1 \mathrm{ml}$ とり PBS で倍 数希釈し，そこに等量の細菌浮遊液を加えて $37^{\circ} \mathrm{C}$ で 2 時間反応させ,一晚水室に放置して翌日凝集 価を判定した。凝集価は $\log _{2}$ で表示した。ただ し, Actinomyces, Leptotrichia および Fusobacterium の 3 菌種の凝集反応は, PBS の代わりに 1 : 250 の割合で Tween 80 を加えた Brain Heart Infusion 培地を用いて行った。 
結

果

\section{1. 分離精製の結果}

濃縮した HPS をDE-52 で分画すると, 主と して，3つのフラクションが得られたが，元のら ち， pH 6.2，0.1M PBS で溶出したピークに抗 IgA 血清と沈降線が生じた。この分画を,さらに Sephadex G-200 でゲル濾過を行うと, void volume 付近で溶出する分画に $\operatorname{IgA}$ 活性が認めら れた。最後に、この分画をBio-Gel A15mでゲル 濾過の精製を繰り返し， 2 番目の IgA rich のピ ークを濃縮して以下の実験に供した。この SIgA 分画を免疫電気泳動して抗 HPS との反応をみる と, 1 本の明膫な沈降線を形成した（図 2 )。

\section{2. $\operatorname{SIgA}$ の同定}

IgA rich の分画が SIgA であることを証明す るために, ゲル内沈降反応と, 免疫電気泳動を行 った。

ゲル内沈降反応では, 抗 SIgA はHS との間 に 2 本の沈降線を形成するが，抗原側の沈降線は $\mathrm{SIgA}$ との1本の沈降線と融合がみられた（図 1)。SIgA と正常血清との沈降線はスパーを形成 して拉りこのスパーは SIgA 中の SC成分によ るものと思われる。

次に, 免疫電気泳動したSIgA 分画と抗 HPS 特

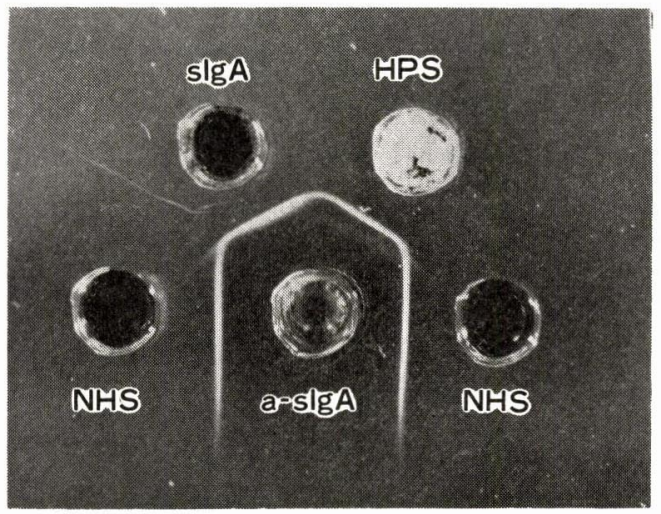

Fig. 1 Ouchterlony analyses of SIgA SIgA: secretory IgA. HPS: human parotid saliva. NHS: normal human serum. a-SIgA: anti-secretory IgA.

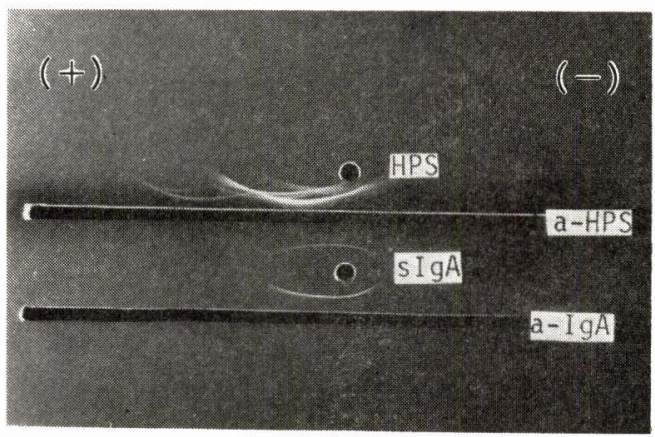

Fig. 2 Immunoelectrophoresis of SIgA against anti-human parotid saliva and anti$\alpha$ chain. Compare with HPS

HPS: human parotid saliva. SIgA: secretory $\operatorname{IgA}$. a-HPS: anti-human parotid saliva. a-IgA: anti-IgA.

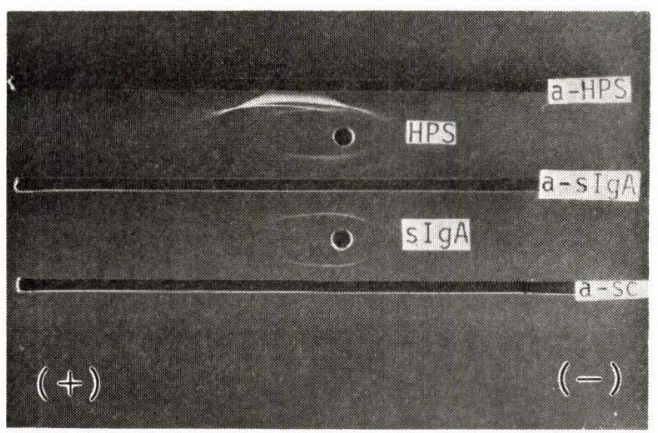

Fig. 3 Immunoelectrophoresis of SIg A against anti-SIgA and anti-sc. HPS is control.

SIgA: secretory IgA. HPS: human parotid saliva. a-SIgA: anti-secretory $\operatorname{IgA}$. a-sc: anti-secretory component. a-HPS: anti-human parotid saliva.

よび抗 $\operatorname{Ig} \mathrm{A}$ 血清との反応では, それぞれ，同一 易動度に明瞭な 1 本の沈降線を形成した（図 2 ）。

同様に, SIgA 分画を免疫電気泳動して, 抗 $\mathrm{SIgA}$ ，抗 SC との反応をみると，同じ易動度内 に沈降線が形成されて拈り, SIgA にはSCが結 合していることがわかった（図 3 )。

以上の結果より, $\operatorname{IgA}$ rich の分画は $\alpha$ 鎖と $\mathrm{SC}$ の両方の抗原性を持っており, SIgA と同定 してもよいことがわかった。

\section{SIgA の常在菌に対する凝集活性}

SIgA が口腔内でいかなる役割を果たしている 
Table 1 Agglutinating activity of SIgA against oral microorganisms

\begin{tabular}{cc}
\hline \hline Bacteria & $\begin{array}{c}\text { Agglutinating } \\
\text { titre }\left(\log _{2}\right)\end{array}$ \\
\hline Streptococcus mutans $\mathrm{HS} 6\left(\mathrm{a}^{*}\right)$ & 2 \\
mutans $\mathrm{Fa} 1(\mathrm{~b})$ & 1 \\
mutans $\mathrm{B} 13(\mathrm{~d})$ & - \\
mutans $\mathrm{LM} 7(\mathrm{e})$ & 1 \\
salivarius 9758 & - \\
sanguis $\mathrm{E} 206$ & 4 \\
mitis 9811 & 2 \\
parvula 17743 & 1 \\
Veillonella alcalescens 17746 & \pm \\
Actinomyces viscosus 15987 & 3 \\
Lactobacillus acidophilus (IAM) & 3 \\
casei (IAM) & \pm \\
fermenti (IAM) & 5 \\
Bacterionema matruchotii 14266 & - \\
Leptotrichia buccalis 14201 & 3 \\
Fusobacterium & 2 \\
Bacteroides melaninogenicus & - \\
Selenomonas & - \\
*Serotype of St. mutans & \\
Initial concentration of SIgA was $120 \mu \mathrm{g} / \mathrm{ml}$ &
\end{tabular}

かを知るためには，まず第 1 に，どのような常在 菌と結合するかが問題になる。この結合の特異性 を知るために, 主要常在菌に対する凝集活性を調 べた。表 1 に示すように 18 株に対する凝集活性を 調べたところ，13株に活性が認められた。特に 強い活性が認められたのは, Lact. fermenti およ びStr. sanguis などに対してであった。しかし， Str. mutans B13, Str. salivarius, Bact. matruchotii, Bact.melaninogenicus およびSelenomonas に対しては凝集がみられなかった。

\section{考察}

唾液中には主要な免疫グロブリンとして, SIgA が存在することが知られている26)。 SIgA はin vitro で先ず抗原である細菌と結合後, 凝集活性 9,24,28)を発揮して拈り，その結果引き続いて起こ る生物学的反応を起こす引き金となると考光られ ている12,28)。一方, 唾液中の細菌はSIgA でおお われていることを Brandtzaeg et al.4) が螢光抗体

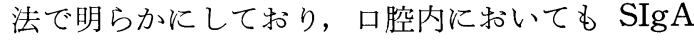
は常在菌を凝集しているものと考光られる。しか しながら，睡液より分離精製した SIgA を用い て，口腔常在菌に対する凝集活性を調べた報告は 少なく $9,24,28), \quad \mathrm{SIg} \mathrm{A}$ が一体, 特異的な凝集活性 を持つかどうかも不明であった。そこで，今回の 実験では，HPS より SIgA を分離精製し，18株 の口腔常在菌に対する凝集活性を調べてみた。

Str. mutans B13, Str. salivarius, Bact. matruchotii, Bact.melaninogenicus おょび Selenomonas の 5 種の細菌に対しては, 凝集活性がみられなか った。実験に使用した SIgA 濃度は, HPS 中に 含まれる IgA 濃度より十分濃いものであるだけ に，それらの菌種に対する凝集活性はかなり低い ものと考光られる。逆に凝集価の高いものとして は, Lact. fermenti, Str. sanguis, Act, viscosus, Lact. casei および Lept. buccalis があげられる。 これらの菌は, HPS 中に含まれる IgA 濃度で十 分に凝集されると思われる。

Str. mutans の Bratthal ${ }^{5)}$ にる血清型分類で, それぞれ a b d e に属する 4 種の菌に対する凝集 活性を調べたところ, a 型で凝集価が最も高く, d 型で最も低い結果が得られた。これは, Arnold, et al. $^{2)}$ が HPSを用いて 5 種類の血清型の Str. mutans に対する凝集価を調べた成績とほぼ一致 する。すなわち，彼らの結果によると a および e 型で凝集価が高く，d型で最も低かった。また, Bratthal ${ }^{6)}$ が報告している Str. mutans の各国に おける血清型別の分布によると, 日本では $\mathrm{c}$ 型と

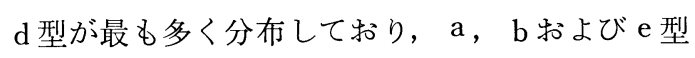
の分布は少ない。颃そらく口腔内においては, a 型の菌などはSIgAによって凝集されてしまい口 腔内に定着しにくいのに対して， $\mathrm{d}$ 型菌などは SIgA による凝集を受けにくいために, 逆に口腔 内に定着しやすいと考光られる。

Gibbons, et al. ${ }^{13)}$ にると, 煩粘膜部には Str. mitis が多く常在して打り, Str. sanguis やStr. salivarius るかなり分布していると報告している。 しかし，それらの菌種に対して特に HPS 中の $\mathrm{SIgA}$ の特異性が上昇あるいは減少している結果 
は得られず, 多菌種にわたって SIgA の凝集活性 が認められた。このことは, 口腔に常在する菌の 間に共通抗原が存在するためとは考㝋にくく，む しろ, 主要常在菌が絶えず弱い抗原刺激を繰り返 す結果, 多くの菌種に対して凝集活性を示すもの と考えられる。すでに, 腸管内でも観察されてい るように ${ }^{14)}$, 口腔内でも正常細菌叢が粘膜局所の $\operatorname{Ig} \mathrm{A}$ 産生に重要なかかわり合いを持っていること を示唆している。

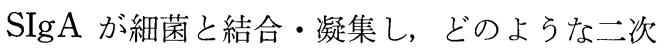
的反応を引き起こすかについての研究は少ない が, Williams, et al. ${ }^{28)}$ によれば HPS 中の SIgA がある種の口腔常在菌を凝集し，その菌が口腔粘 膜上皮細胞へ付着するのを阻止しているといら。 同様の活性は, 混合唾液中に含まれる糖蛋白 11,15 , ${ }^{18,29)}$ にも存在すると考光られている。また Ørstavik, et al. ${ }^{20)}$ によれ゙, HPSはStr. sanguis や Str. salivarius を凝集し，それらの菌がペリクル へ付着するのを抑制していると報告しているが, このよらな活性が SIgA とも認められるかどうか は興味のある問題である。

このように, SIgA の凝集が口腔内でどのよう な役割を果たしているかについての報告は少な く，また，非特異的凝集因子である糖蛋白とどの ようなかかわり合いを持っているかも不明であ る。今後, これらの問題について研究を進めて行 く予定である。

\section{謝 辞}

稿を終えるにあたり，ご指導とご校閲を賜りまし た堀川高大教授に謹んで感謝の意を表します。また 終始ご指導ご援助をいただきました斎藤祐一助教授 ならびに口腔細菌学教室の諸先生方に心から打礼申 し上げます。

\section{文献}

1) Adinolfi, M. et al.: Serological properties of $\gamma \mathrm{A}$ antibodies to escherichia coli present in human colostrum. Immunology, 10: 517-526, 1966.

2) Arnold, R. R. et al.: Naturally occurring secretory immunoglobulin a antibodies to strepto- coccus mutans in human colostrum and saliva. Infec. Immun., 14: 355-362, 1976.

3) Artenstein, M. S. et al.: Identification of the antiviral substances in nasal secretions. Proc. Soc. Exptl. Biol. Med., 117: 558-562, 1964.

4) Brandtzaeg, P. et al.: Adsorption of immunoglobulin a onto oral bacteria in vivo. J. of Bact., 96: 242-249, 1968.

5) Bratthall, D.: Demonstration of five serological groups of streptoccocal strains resembling streptococcus mutans. Odonotol. Revy, 21:143 $-152,1970$.

6) Bratthall, D.: Demonstration of streptococcus mutans strains in some selected areas of the world. Odont. Revy, 23: 401-410, 1972.

7) Douglas, R. G. et al.: Rhinovirus neutralizing antibody in tears, parotid saliva, nasal secretion and serum. J. of Immunol., 99: 297-303, 1967.

8) Falkler, W. A. Jr. \& Hawley, C. E.: Hemagglutinating activity of fusobacterium nucleatum. Infec. Immun., 15: 230-238, 1977.

9）福田富男：分泌型 IgA の精製と口腔内細菌に対 する抗体活性について. 歯基礎誌, $16: 395-$ 406, 1974.

10) Gibbons, R. J. \& Macdonald, J. B.: Hemin and vitamin $\mathrm{K}$ compounds as required factors for the cultivation of certain strains of bacteroides melaninogenicus. J. Bact., 80: 164-170, 1960.

11) Gibbons, R. J. \& Spinell, D. M.: Salivary-induced aggregation of plaque bacteria.: in MacHugh Dental plaque. Livingstone, 1970, Edinburgh, pp. 207-215.

12) Gibbons, R. J.: Bacterial adherence to mucosal surfaces and its inhibition by secretory antibodies. Adv. Exp. Med. Biol., 45: 315-325, 1974.

13) Gibbons, R. J. \& Houte, J. van.: Bacterial adherence in oral microbial ecology. Annual R. Microbiol., 29: 19-44, 1975.

14) Grabbé, P. A., et al.: The normal microbial flora as a major stimulus for proliferation of plasm cells synthesizing $\operatorname{IgA}$ in the gut. Int. arch. allergy, 34: 362-375, 1968.

15) Hay, D. I. et al.: Characteristics of some high molecular weight constituents with bacterial aggregating activity from whole saliva and dental plaque. Caries Res., 5: 111-123, 1971.

16) Hill, I. R. \& Porter, P.: Studies of bactericidal activity to escherichia coli of porcine serum and colostral immunoglobulins and the role of lysozyme with secretory IgA. Immunology, 26: 1239-1250, 1974. 
17) Hurliman, J. \& Zuber, C.: In vitro protein synthesis by human salivary glands. 1 . Synthesis of salivary $\operatorname{IgA}$ and serum proteins. Immunology, 14: 809-817, 1968.

18) Kondo, W., et al.: Properties of the human salivary aggregating factor for Leptotrichia buccalis cells. Archs oral Biol., 23: 453-458, 1978.

19) Ogra, P. L.: Antiviral aspects of local immunity. Mergenhagen, S. E. \& Scherp, H. W. Comparative immunology of the oral cavity. Maryland, 1973, N. I. H., pp. 38-67.

20) Ørstavik, D., et al.: In vitro attachment of Streptococci to the tooth surface. Infec. Immun., 9: 794-800, 1974.

21) Rogosa, M. \& Bishop, F. S.: The genus Veillonella. 2. Nutritional studies. J. of Bact., 87: 574-580, 1964.

22) Saito, Y.: Biological activity of papain digested Streptococcal anti-M antibody. J. J. Micro., 13: 19-28, 1969.

23）斎藤祐一，他：分泌型 $\operatorname{IgA}$ の生物学的活性一特 に抗菌免疫を中心として一. 口病誌, $43: 1-6$,
1976.

24) Sirisinha, S.: Reaction of human salivary immunoglobulins with indigenous bacteria. Archs oral Biol., 15: 551-554, 1970.

25) Toda, H.: Studies on the oral anaerobic motile fusiform bacilli. Bull. Tokyo Med. Dent. Univ., 15: 133-159, 1968.

26) Tomasi, T. B., et al.: Characteristic of an immune system common to certain external secretions. J. Exp. Med., 121: 101-124, 1965.

27) Tourville, D. T., et al.: Natural antibodies of human serum, saliva and urine reactive with Escherichia coli. Proc. Soc. exp. Biol. Med., 128: 722-727, 1968.

28) Williams, R. C. \& Gibbons, R. J.: Inhibition of bacterial adherence by secretory immunoglobulin A: A mechanism of antigen disposal. Science, 177: 697-699, 1972.

29) Williams, R. C. \& Gibbons, R. J.: Inhibition of streptococcal attachment to receptors on human buccal epithelial cells by antigenically similar salivary glycoproteins. Infec. Immun., 11:711-718, 1975. 